\title{
REWARDING TAX COMPLIANCE: TAXPAYERS' ATTITUDES AND BELIEFS
}

\author{
Marina Bornman* \\ University of Johannesburg \\ mbornman@uj.ac.za
}

Received: September 2014

\author{
Lilla Stack* \\ Rhodes University \\ e.stack@ru.ac.za
}

Accepted: September 2015

\begin{abstract}
In a society the tax climate is determined by the interaction between taxpayers and tax authorities. In a 'service and client' climate, taxpayers do not expect authorities to automatically suspect them of being tax evaders. Evidence suggests that recognising good tax behaviour with strategies of rewards has a positive effect on voluntary tax compliance. Principles derived from the cognitive evaluation theory predict that when feelings of competence are affirmed and this is accompanied by a sense of autonomy it can enhance the intrinsic motivation for an action. The present research surveyed the attitudes and beliefs of taxpayers involved in small business on being rewarded for tax compliance. Results were corroborated with the principles of the cognitive evaluation theory and it was found that that the principles of the theory are applicable to rewarding tax compliance behaviour.
\end{abstract}

Keywords

Tax compliance; rewards; cognitive evaluation theory; intrinsic motivation; voluntary tax compliance; taxpayers' attitudes and beliefs; penalties

*Dr M Bornman is a senior lecturer in the Department of Accountancy, University of Johannesburg, South Africa.

\#Prof $\varepsilon$ Stack is professor in the Department of Accounting, Rhodes University, Grahams town, South Africa. 


\section{INTRODUCTION}

Research into tax compliance behaviour has recognised the importance of interactions amongst the various entities involved in the taxation process, in particular the interaction between taxpayers and tax authorities, and the impact of the dynamics of these interactions on the actual level of tax compliance (Kirchler, Muehlbacher, Kastlunger \& Wahl (2007); Pickhardt \& Prinz (2014)).

SARS describes tax compliance as "the degree to which taxpayers and traders, along with intermediaries like practitioners and clearing agents, meet their legal obligations" (SARS, 2012).

Feld and Frey (2007) proposed that a psychological contract exists between taxpayers and tax authorities. This contract is based on trust and implies that authorities expect taxpayers to declare their true income honestly; and taxpayers expect authorities to treat them respectfully and not suspect or assume them to be tax evaders. Alm, Kirchler and Muehlbacher (2012:144) add that the disappointment of expectations represents a violation of the contract with a resulting negative impact on willingness to cooperate.

A tax climate in a society can range on a continuum from an antagonistic to a synergistic climate. The characteristics linked to these climates then, respectively, vary from a 'cops and robbers' attitude on the part of both tax authorities and taxpayers, to a 'service and client' attitude (Kirchler, Hoelzl, \& Wahl, 2007). In the synergistic climate, a posture of cooperation will prevail with low social distance and likely voluntary compliance.

It can be argued that the South African Revenue Service (hereafter referred to as SARS) displays a 'service and client' attitude. This is evident from its adoption of the tax compliance model developed by the Cash Economy Task Force (1998) for the Australian Tax Office, based on the influential work on motivational postures of taxpayers by Valerie Braithwaite (2002). In this model, the assumption is made that the majority of taxpayers are voluntarily compliant and should accordingly be approached by tax authorities with an attitude of service. The tax compliance model is illustrated by FIGURE 1 .

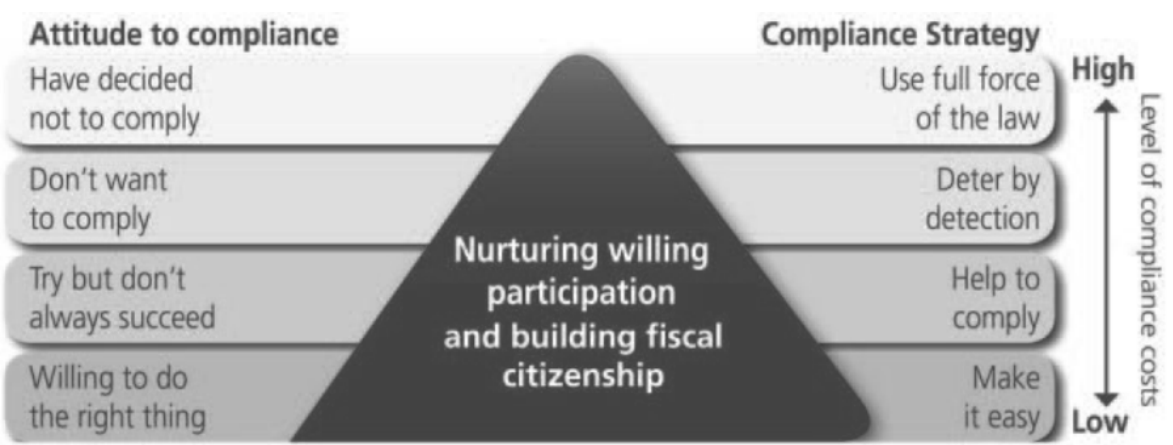

\section{FIGURE 1: The tax compliance model}

Source: SARS, 2012:4

SARS released its first tax compliance programme during 2012, providing an overview of its strategies for the next five years to increase compliance with tax legislation, with particular attention on areas that pose a significantly higher risk of non-compliance. In this document, small businesses are identified as a compliance risk area. SARS indicates that its aim is to make 
meeting tax obligations simpler for small businesses and at the same time entrench a culture of voluntary compliance (SARS, 2012).

SARS acknowledges the vital role that small businesses play in stimulating economic activity, job creation, poverty alleviation and the general upliftment of living standards (SARS, 2012:18). However, it is questionable whether SARS appreciates and acknowledges small businesses for being tax compliant. A study by Smulders and Naidoo (2013) investigated the extent to which SARS has been addressing the tax compliance burden of small businesses in South Africa. They state that initiatives undertaken by SARS to address the tax compliance needs of small businesses will empower small business in South Africa to grow and develop. The present article suggests that SARS could also do more to acknowledge and reward small businesses which are found voluntarily compliant, and proposes that such a strategy could enhance the building of a voluntary tax culture amongst small businesses in South Africa.

This article aims to address two problems. Firstly, although experimental research has been conducted before on the effect of rewards on tax compliance behaviour, no research to determine the attitudes and beliefs of taxpayers on the use of rewards as a positive incentive to encourage tax compliance has been done. Secondly, in earlier research investigating the possibility of rewarding tax compliant behaviour, certain authors made use of the cognitive evaluation theory of Ryan and Deci (2000), which provides insight into the effect of rewards on intrinsically motivated behaviour. But whether the theoretical principles derived from the cognitive evaluation theory hold true for tax compliance behaviour has not yet been evaluated in previous research.

The objective of this article is to present and analyse the attitudes and beliefs expressed by owners, managers and other role players in small businesses in the real estate and construction industry in Ekurhuleni, South Africa, on the possibility of being rewarded for their tax compliant behaviour. This analysis is then to be used to corroborate the principles derived from the cognitive evaluation theory with the rewarding of tax compliant behaviour.

\section{ENCOURAGING AND REWARDING TAX COMPLIANCE: THEORETICAL BACKGROUND}

\subsection{Penalties and Tax Compliance}

Traditional methods of enforcement through audit and penalties explain only a small fraction of tax compliance and many studies show that penalties correlate weakly with tax compliance (see Feld \& Frey (2003); Frey \& Holler (1998) and Tyler (2006)). Torgler (2003) remarked that the tax authority cannot achieve the total compliance of tax evaders unless there 'is a tax administrator under every bed'. Deterrence has also been regarded as ineffective when dealing with those taxpayers whose non-compliance is unintentional, since it may have the undesired effect of these taxpayers losing confidence in the fairness of the tax system (National Taxpayer Advocate, 2010).

Grasmick and Scott (1982) found that fear of audits and penalties are not the most important reasons why people pay taxes, and Tyler (2006) suggests that authorities turn their attention to taxpayers' additional motivations for obeying the law (such as morality and social norms) and employ an approach of procedural justice. The Cash Economy Task Force (2003) suggests in its report to the Australian Tax Office that the focus should be on ensuring future compliance when dealing with admitted non-compliers and that follow-up contact could be more effective than a once-off penalty. 
To enforce penalties and sanctions need not be the only form of power exercised by authorities. Turner (2005) reasons that power exercised by authorities can be 'influential' or 'controlling'. She describes 'power as influence' as the act of persuading people that a desired action is correct, moral, or appropriate. People are then likely to cooperate voluntarily and act out of their own resolution. 'Power as control' is the capacity to get people to act when they are not persuaded or are not interested in the validity of the specific belief or act. Turner further states that controlling power can take two forms, namely coercive and legitimate power. Coercive power means that the authority resorts to actions such as penalties and sanctions to manipulate behaviour. It is directed at forcing people to comply on an involuntary basis. Legitimate power, on the other hand, is control based on the acceptance by people of the authority's right to prescribe its beliefs, attitudes or actions. In other words, even if one does not agree with a prescribed action, one ascribes to the legitimacy of the authority and still voluntarily submits.

It is therefore submitted that authorities can also exercise power by giving rewards to compliant taxpayers as an act of persuading people to do the right thing. This will signal influential power. Legitimate power will, however, be a necessary pre-condition to and is dependent on trust in the authorities. Kastlunger, Lozza, Kirchler and Schabmann (2013) confirmed that legitimate power depends on trust with their finding that citizens who trusted the authorities perceived effective authorities as strong and powerful; however, citizens who do not trust the authorities perceived the same strength as coercive and enforcing.

\subsection{Experimental research on the effect of rewards on tax compliance behaviour}

According to Feld, Frey and Torgler (2006) a persistent theme in the tax compliance literature in the last few years is to move away from deterring non-compliance and towards positive encouragement for compliance, therefore emphasising the use of the 'carrot' for compliance rather than the 'stick' for non-compliance. From the literature, it appears that five experimental studies have been carried out to investigate the effect of rewards on tax compliance behaviour. These are briefly discussed below.

Alm, Jackson and McKee's (1992) study was conducted with students, repeated over a number of rounds, during which they are given tokens (as income) the amount of which was randomly selected by a computer. The students were then required to decide how much of this income to report for tax purposes. Alm et al. (1992) designed three treatments for rewarding tax compliance in the experimental setting. The treatments were (i) participants who were found to be fully compliant for the current and the previous four rounds could enter into a lottery with a substantial prize; (ii) a fixed reward session where fully compliant participants received a reward of 2 tokens; and (iii) an audit reduction session where the probability of a future audit was reduced significantly. Their results indicated that the positive treatments had a significant and positive impact on compliance, with the lottery treatment having the largest impact.

In a tax compliance experiment with taxpayers in Costa Rica, Torgler (2003) used three treatments on three different groups and compared their behaviour with a control group. One of the groups had a positive reward session - which means that participants were audited and if found to be fully honest, received a monetary reward. The other two groups were subjected to a fiscal exchange equity treatment and a moral suasion treatment. The three treatments are briefly explained below. 
- The positive reward treatment consisted of a monetary reward paid to participants who were audited and found to be fully compliant.

- Fiscal exchange equity refers to the perceived fairness of what taxpayers receive from the government in exchange for their paid taxes (Torgler, 2003). The fiscal exchange treatment involved the provision of a public good in exchange for the respondents' taxes paid, resulting in a surplus which was then distributed to the members of the group.

- The moral suasion treatment consisted of a short statement provided to the participants that read as follows:

Although we will not be able to find out who among you might have been dishonest we want to point out that we greatly appreciate your behaving honestly and paying back the whole amount we have asked you for.

Although tax compliance was very high in all three groups relative to the control group, the highest tax compliance rate was found in the positive reward session, followed by the moral suasion and then the fiscal exchange treatment. Torgler does warn, however, that the experiment was conducted over one round only and that the sample size was very small, but, on the other hand, the experiment was conducted with real taxpayers and real money - unlike many other experiments that are conducted with students.

Kastlunger, Muehlbacher, Kirchler and Mittone (2011) conducted a study with 86 students using two reward conditions (a high and a low reward) and a control group. All groups had the same tax rate and audit probability and were told that in the case of an audit there would be an additional fine if they were found to be non-compliant. Sixty experimental rounds were played during which the participants had to declare and pay their taxes using a computer-aided experiment. Their results indicated that no significant differences emerged between the three groups, but it was revealed that different taxpaying strategies were followed in the reward conditions. An 'all-ornone behaviour' (that is, paying all or nothing of one's tax due) was observed to be more pronounced when rewards were provided. Kastlunger et al. (2011:162) interpreted this finding saying that when the prospect of a reward for honesty is provided, taxpayers either go for the additional income from tax evasion or they head toward obtaining the reward. They did find, however, that completely honest tax reports were more often observed in the reward conditions, and state that it appears that rewards have increased the tax payments of 'mild-evaders.'

Callihan and Spindle (1997) studied the effects of varying reward structures on responses to a tax compliance decision task. A scenario was presented to 128 post-graduate students in which they assumed the role of a taxpayer. Three different reward structures were used: grade-point credits for participation; non-contingent monetary compensation for participation; and monetary compensation contingent on performance. Audit probabilities and penalty rates were held constant across subjects. Two patterns emerged from their results: first there was a strong tendency for subjects to report all of the income regardless of the reward structure. Second, those who chose to report no income also did it regardless of the reward structure. Their findings further indicated that there was no statistical difference on income reported between the subject receiving extra credit and those receiving a non-contingent monetary reward for participation. The contingent reward structure, however, resulted in less income reported, but with little statistical significance.

Bazart and Pickhardt (2009) conducted various sessions with students in a non-computerised setting. In each session, five students were 'acting subjects', one student acted as 'the institution' and another student performed the role of the 'public good calculator'. Each of the five acting subjects received an endowment or income of 100 tokens per round, i.e. $W=100$, and 
was told that according to a generally accepted rule he or she is supposed to give up 20 of the 100 tokens in each round by submitting these 20 tokens to a third party called 'institution'. After a couple of rounds, a higher auditing rate was introduced. Participants could choose between the higher or lower audit rate, but a positive incentive in the form of an individual lottery prize for fully honest taxpayers was introduced as well. Their results from various sessions provide evidence suggesting that positive rewards in the form of an individual lottery have a strong positive impact on tax compliance. This positive impact was particularly strong for male taxpayers. Although the experiment made use of students, Bazart and Pickhardt (2009) state that their design is close to a real-world environment.

For most of the above experiments, the researchers conclude that governments should pursue a range of approaches to promote compliance and should look beyond strategies of greater enforcement.

\subsection{The concept of rewarding voluntary tax compliance}

Bornman (2014:255) defined a reward for tax compliance as:

an incentive of a tangible or relational nature administered by a tax authority with the objective of encouraging voluntary compliance by taxpayers.

Bornman (2014) explains that a reward is not a tax incentive, a tax holiday, a rebate, or a tax amnesty, as these strategies usually do not have the objective to reward tax compliance.

The definition refers to a reward as a token given to eligible taxpayers of a tangible or relational nature. In reviewing some reward strategies used in a number of countries, it was found that there are countries which make use of certificates to exemplary taxpayers, privilege cards offering benefits to compliant taxpayers and lotteries to reward those taxpayers who submit tax returns electronically (Bornman, 2014). Public 'thank you' messages by the tax authority and public communication of how taxes contribute to the common good, are also experienced as 'rewarding their tax compliance' by taxpayers (Bornman, 2014).

\subsection{The cognitive evaluation theory as the basis for rewarding voluntary tax compliance}

In order to apply the principles of the cognitive evaluation theory as postulated by Deci, Koestner and Ryan (1999) to rewards given for being tax compliant, it is important to understand the intrinsic nature of voluntary compliance. According to Ryan and Deci (2000), true intrinsic motivation refers to doing something because it is inherently interesting or enjoyable. Tax compliance behaviour may fall into this category for some people, but three other forms of behaviour as defined by Ryan and Deci (2000) that range from somewhat externally to somewhat internally motivated behaviour are probably more relevant to tax compliance. Ryan and Deci (2000) explain that the more internal the locus of control is perceived to be, the more 'intrinsically motivated' the action will be. The application of this to tax compliance behaviour is illustrated in TABLE 1. 
TABLE 1: Motivational tendencies of voluntary tax compliance

\begin{tabular}{|c|c|c|c|c|c|}
\hline \multirow{2}{*}{$\begin{array}{l}\begin{array}{l}\text { Motivational } \\
\text { tendency }\end{array} \\
\begin{array}{l}\text { Behavioural } \\
\text { regulation }\end{array}\end{array}$} & \multicolumn{3}{|c|}{ Extrinsically to Intrinsically Motivated } & \multirow{2}{*}{$\begin{array}{l}\text { Purely } \\
\text { Intrinsically } \\
\text { Motivated }\end{array}$} & \\
\hline & Introjected & Identification & Integration & & \\
\hline $\begin{array}{l}\text { Reason for } \\
\text { compliance }\end{array}$ & $\begin{array}{l}\text { Attaining } \\
\text { particular benefits } \\
\text { or avoiding } \\
\text { punishments }\end{array}$ & $\begin{array}{l}\text { Believing it is } \\
\text { important for the } \\
\text { common good }\end{array}$ & $\begin{array}{l}\text { Personal and } \\
\text { social norms / } \\
\text { ethical values }\end{array}$ & $\begin{array}{l}\text { Enjoyment } \\
\text { Satisfaction/ } \\
\text { Challenge }\end{array}$ & / \\
\hline $\begin{array}{l}\text { Locus of control } \\
\text { / Autonomy }\end{array}$ & $\begin{array}{l}\text { Somewhat } \\
\text { external, } \\
\text { somewhat internal }\end{array}$ & Internal & Internal & Internal & \\
\hline
\end{tabular}

Source: Bornman (2014:264)

According to cognitive evaluation theory, the psychological need for autonomy and competence underlies intrinsic motivation, so that the effects of a reward depend on how it affects perceived self-determination and perceived competence (Deci et al., 1999). Ryan and Deci (2000:58) argue that when feelings of competence are affirmed during action (for example, with rewards, communication or feedback), it can enhance the intrinsic motivation for that action because it satisfies the basic psychological need for competence. Cognitive evaluation theory further specifies that feelings of competence will not enhance intrinsic motivation unless they are accompanied by a sense of autonomy, also referred to as an internally perceived locus of causality (Ryan \& Deci, 2000:58). In other words, a high level of intrinsic motivation is dependent on the satisfaction of the need for both competence and autonomy; cognitive evaluation theory predicts that rewards that are perceived as controlling will decrease intrinsic motivation.

As can be seen from TABLE 1 , an internal locus of control is connected to (1) a belief that the behaviour is important for the common good; (2) behaviour induced by personal and social norms; and (3) behaviour based on enjoyment or a challenge. Therefore, a reward that affirms the recipient's autonomy in completing the task should convey a message that recognises its behaviour. For example, a reward could make the taxpayer feel appreciated for doing the right thing, or could give recognition to the taxpayer for contributing to the well-being of the country. The New Zealand Revenue Authority used a comic strip ending with the words: 'There is a compliance superhero in each of us' (OECD, 2009:48). This could be seen as a message that provides recognition to taxpayers for being tax compliant.

In summary, the principles derived from the cognitive evaluation theory to take into account in rewarding tax compliant behaviour are:

- the reward should affirm the competence of the taxpayer;

- the reward should give the taxpayer the appropriate recognition;

- a reward that conveys appreciation with the awarding of it will be perceived as less authoritarian, and is therefore less likely to be experienced as controlling. 


\section{METHODOLOGY}

A semi-structured questionnaire was developed to measure attitudes and beliefs on rewarding tax compliant behaviour. The questionnaire first dealt with socio-demographic aspects, followed by a number of statements pertaining to aspects of how respondents would experience being rewarded for tax compliant behaviour. Respondents could indicate the extent to which they agree or disagree with the statements on a five-point Likert-type scale. Leedy and Ormrod (2010:189) confirm that rating scales such as the Likert scale are useful when an attitude needs to be evaluated. The questionnaires were administered face to face to owners, managers, or prominent employees of small business during November 2013 with the assistance of six fieldworkers. In 18\% of the small businesses, the fieldworker could not gain access to the owner, manager or bookkeeper. Also see discussion under section 3.1 in this regard. The fieldworkers were trained by the researcher. The questionnaires were checked for ambiguity by running a pilot with a number of colleagues and postgraduate students and was also approved in terms of layout, coding and consistency by the Statistical Consultation Service (Statkon) of the University of Johannesburg. A cover letter accompanied each questionnaire to explain the purpose of the study and to assure confidential treatment of the responses. No respondent was required to affix his/her name on the questionnaire, nor was any business premises identified by name or address on the questionnaire.

\subsection{Population and sampling}

Ekurhuleni is a metropolitan area in Gauteng, South Africa, covering an area of 1975 square kilometres and includes nine towns and 13 townships (towns where, traditionally, mainly black South Africans live). Approximately 3178470 people (or 6\% of South Africa's population) reside in Ekurhuleni (EMM, 2013). The area contributes approximately $18 \%$ to the total economic output of the Gauteng province, is home to South Africa's biggest international airport and is considered to be an economically active area with a large diversity of industries.

Respondents were selected from the construction industry (including contractors, such as plumbers and electricians) and the real estate industry, using quota sampling. The reason for selecting these two industries is that, according to research done by the Commonwealth Association of Tax Administrators, the construction industry and self-employed contractors are regarded as the most likely to engage in tax evasion, with taxi drivers and estate agents in third and fourth place on the list (The Commonwealth Association of Tax Administrators, 2006:99). Since no reliable database of all small businesses in Ekurhuleni exists, a list of business names was compiled using the electronic telephone directory (the electronic Yellow Pages) as well as the Estate Agents Affairs Board website. Fieldworkers were provided with a list with contact details for a total of 230 construction-type businesses and 530 real estate agencies, grouped per town. Final inclusion in the sample was based on voluntary participation. Each fieldworker was instructed to collect 30 completed questionnaires, using a mix of contractors and estate agents. They could make appointments by phone or simply walk in and ask for voluntary participation. A total of 176 completed questionnaires were collected and used in the analysis.

\subsection{Data analysis technique}

The data was captured using the IBM SPSS Statistics software package (commonly known as SPSS) and was summarised in the form of frequencies and percentages in a report format. The report 
was analysed using descriptive statistics and relevant statistical tests to compare results for different groups.

\section{RESULTS AND DISCUSSION}

\subsection{Demographic information}

The demographic characteristics of the sample are displayed in TABLE 2.

\section{TABLE 2: Demographic information $(n=176)$}

\begin{tabular}{|c|c|c|}
\hline \multicolumn{2}{|r|}{ Variable } & \multirow{2}{*}{$\frac{\text { Frequency }}{\%}$} \\
\hline & & \\
\hline \multirow[t]{2}{*}{ Gender } & Male & 58.5 \\
\hline & Female & 41.5 \\
\hline \multirow[t]{5}{*}{ Age } & $20-25$ & 9.8 \\
\hline & $26-35$ & 35.0 \\
\hline & $36-45$ & 32.5 \\
\hline & $46-55$ & 14.1 \\
\hline & 56 and older & 8.6 \\
\hline \multirow[t]{4}{*}{ Ethnicity } & Black & 38.1 \\
\hline & White & 44.9 \\
\hline & Coloured & 8.0 \\
\hline & Indian or Asian & 9.1 \\
\hline \multirow[t]{3}{*}{ Educational level } & Grade 12 and lower & 44.2 \\
\hline & Post-matric diploma or certificate & 34.5 \\
\hline & Degree or post-graduate & 21.3 \\
\hline \multirow[t]{3}{*}{ Type of industry } & Estate agent & 35.4 \\
\hline & Construction & 57.3 \\
\hline & Other & 7.3 \\
\hline \multirow[t]{3}{*}{ Size of the business } & Work alone & 3.4 \\
\hline & $1-10$ employees & 65.7 \\
\hline & More than 10 employees & 30.9 \\
\hline
\end{tabular}

Source: Authors' results

The majority of the respondents were the owners of the respective businesses ( $55 \%$ ), with $27 \%$ of the respondents being managers or bookkeepers and the remaining $18 \%$ mainly being estate 
agents (in the case of estate agencies), with single incidences of the respondents being a foreman, a sales person or an administrative clerk in other cases.

It could be argued that not all of the respondents are small business owners and are therefore not qualified to respond to questions relating to the tax compliance of the business. Ninety-four per cent (or 166 respondents) of the sample indicated that they are aware of what the standing of the particular business is with SARS, in respect of meeting its tax obligations. Within this group of 166 respondents, $82 \%$ indicated that the tax function is their responsibility. This indicates that they could participate meaningfully in the survey and their participation is therefore justified.

A total of 141 respondents indicated that the business makes use of a tax practitioner to complete tax returns, that is, almost $80 \%$. Earlier research by Langham, Paulsen and Hartel (2012) indicated that taxpayers' reliance on tax practitioners may decrease their tax awareness and may actually reduce levels of voluntary compliance. The implication for the survey is that some respondents may have low levels of tax awareness as they leave the tax decision in the hands of a tax practitioner. This may result in them reacting apathetically to the questionnaire. On the other hand, the fact that so many of the businesses make use of a tax practitioner might be an indication of high levels of compliance by the majority of the sample.

\subsection{Summary of attitudes and beliefs expressed by the respondents in respect of the statements on the use of rewards for tax compliance}

A summary of responses on the statements eliciting opinions on certain aspects pertaining to the receipt of a reward for being tax compliant is presented in TABLE 3. (The meaning of the term "tax compliance" was provided in the introduction to the questionnaire.)

TABLE 3: Summary of respondents attitudes and beliefs $(n=171)$

\begin{tabular}{|c|c|c|c|}
\hline Statement & $\begin{array}{l}\text { Mean } \\
\text { (between } \\
1 \text { and 5) }\end{array}$ & Mode & $\begin{array}{l}\text { Standard } \\
\text { deviation }\end{array}$ \\
\hline $\begin{array}{l}\text { 1. I believe rewarding citizens' tax compliant behaviour (as } \\
\text { opposed to punishing non-compliant behaviour) could } \\
\text { result in more people paying their taxes. }\end{array}$ & 3.92 & 5 & 1.133 \\
\hline $\begin{array}{l}\text { 2. I believe one should not be rewarded for being tax compliant } \\
\text { since it is expected from all citizens by law to be tax } \\
\text { compliant. }\end{array}$ & 2.64 & 2 & 1.328 \\
\hline $\begin{array}{l}\text { 3. To be rewarded for being tax compliant will confirm my } \\
\text { competence in dealing with my tax affairs. }\end{array}$ & 3.71 & 4 & 1.018 \\
\hline $\begin{array}{l}\text { 4. A reward scheme will make me feel I am being appreciated } \\
\text { by government for being tax compliant. }\end{array}$ & 3.77 & 4 & 1.080 \\
\hline $\begin{array}{l}\text { 5. A reward scheme will make me believe that government is } \\
\text { serious about acknowledging citizens as important role } \\
\text { players in the economic wellbeing of the country. }\end{array}$ & 3.89 & 4 & 1.080 \\
\hline
\end{tabular}

Source: Authors' results

Respondents could select a value on the Likert-type scale ranging from $1=$ strongly disagree to 5 = strongly agree. Respondents also had the option to select "neutral" by selecting a 3 on the scale. According to Leedy and Ormrod (2010:190), there are mixed views among experts about letting 
respondents remain neutral in a questionnaire. Given the unfamiliar concept of rewarding tax compliance behaviour, it was decided to include this option in the present research.

The number of respondents who responded to all the statements is 171 . In the detailed analysis that follows (FIGURES 2 to 6 ), the actual number of responses per question is used. The detailed responses to statement 1 relating to respondents' attitudes and beliefs on rewards versus punishments as a strategy to encourage tax compliance are illustrated in FIGURE 2.

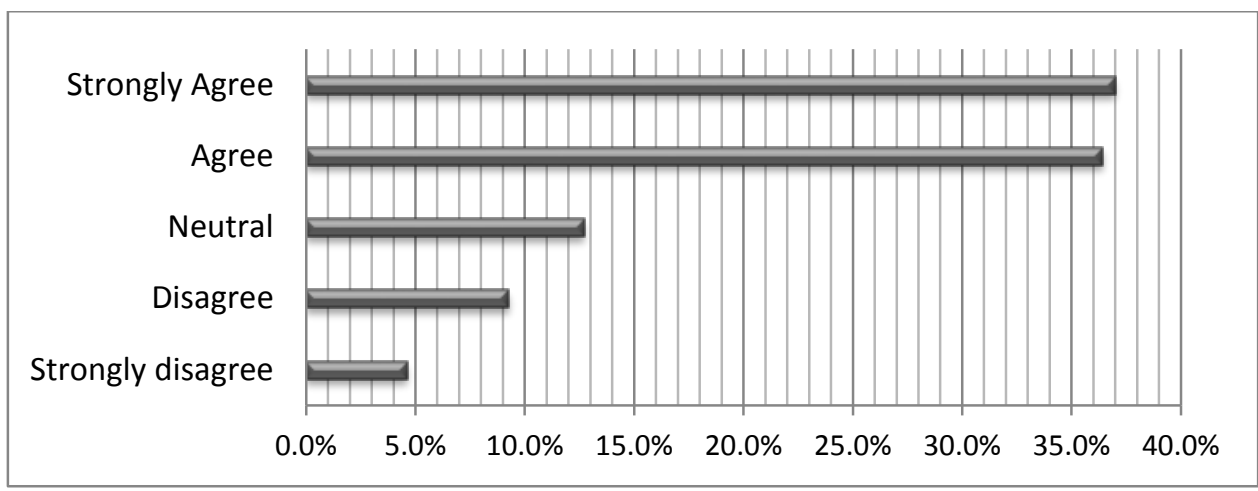

FIGURE 2: Responses to statement $1(n=173)$

Source: Authors' results

The majority of the respondents are in agreement that rewards could be more effective than penalties in encouraging compliance. Previous research found that penalties for non-compliance do not have the desired effect. For example, a study by Martin and Dolan (2010) found that tax fraud increased in the United States in the year following the introduction of a series of additional penalties for tax non-compliance. Similar reports about the ineffectiveness of penalties were made by Murphy (2005) and Torgler (2003). The fact that the majority of respondents support the rewarding of tax compliance is congruent with the finding by Grasmick and Scott (1982), who reported that fear of audits and penalties is not listed by individuals as the main reason why they are paying taxes.

Statement 2 gives an indication of respondents' beliefs about being rewarded for doing one's civic duty. FIGURE 3 illustrates the responses in detail.

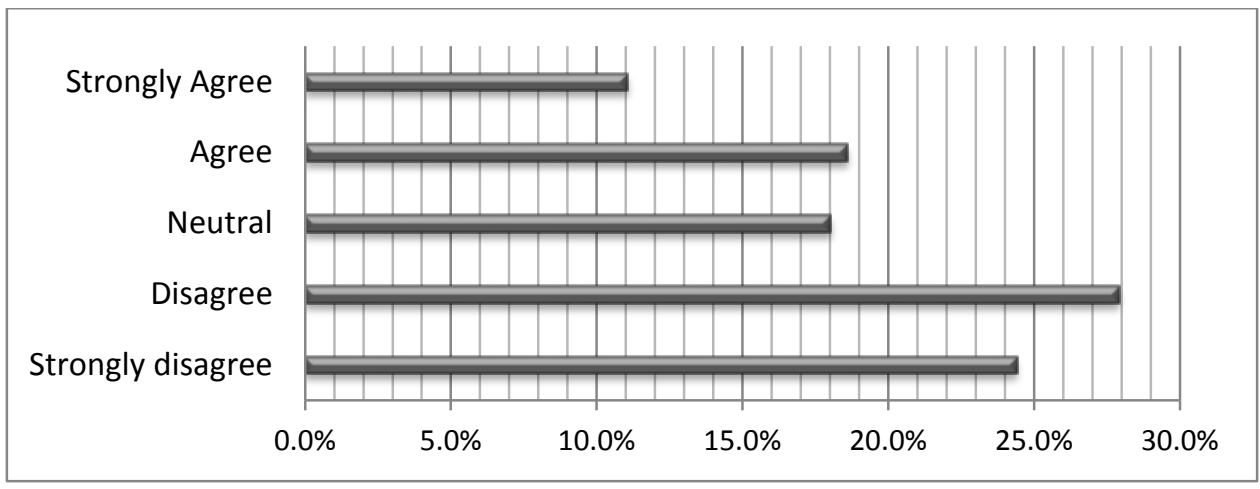

FIGURE 3: Responses to statement $2(\mathbf{n}=\mathbf{1 7 2})$

Source: Authors' results 
Less than $30 \%$ of the respondents believe that one should not be rewarded for an action required to be performed by law. This appears to be in agreement with a study by Fehr and Falk (2002), who reasoned that to pay people for their moral behaviour is a contradiction in itself because it means that their behaviour can no longer be considered as moral. Ariely, Bracha and Meier (2009) also reason that people want to be seen by others as doing good, but if one receives an extrinsic incentive, the signal of a prosocial act is diluted, and the image value decreases, thus the prosocial behaviour may decrease.

In the results of the present survey, the majority of respondents do not agree with the statement that one should not be rewarded for tax compliance, but not by an overwhelming majority (52\%); $18 \%$ of the respondents were indifferent. A study by Lacetera and Macis (2010) on incentivising blood donation showed that donors were likely to stop donating if cash rewards are introduced, but the effect was much smaller when rewards in the form of vouchers were introduced. It can therefore be argued that the type of reward may play a role in the acceptance of a strategy of rewarding tax compliance by taxpayers.

Statement 3 related to one of the principles of the cognitive evaluation theory, namely that to be rewarded for being tax compliant will confirm the taxpayers' competence in dealing with their tax affairs.

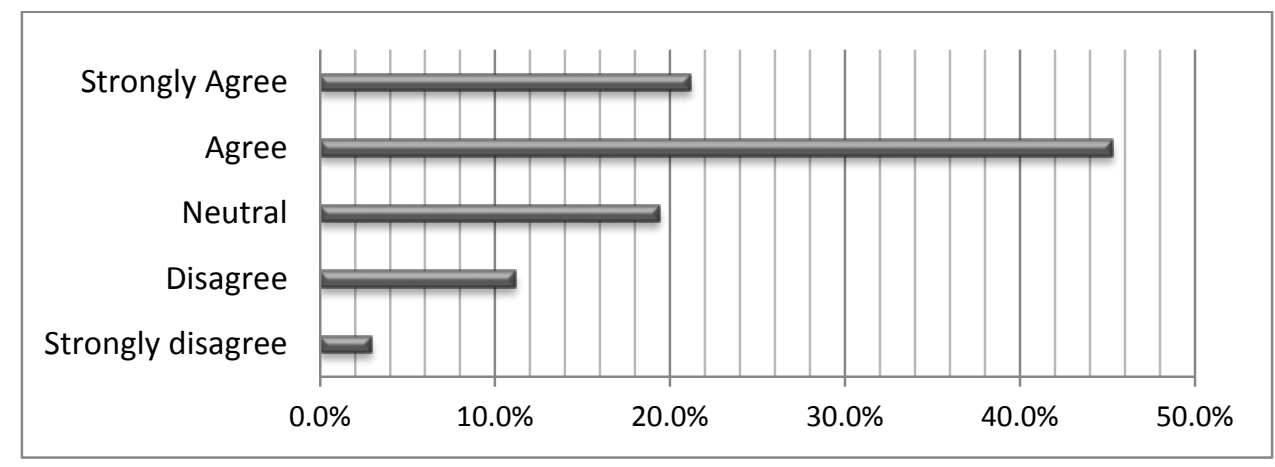

\section{FIGURE 4: Responses to statement $3(n=170)$}

Source: Authors' results

A distinct majority of the respondents (66.5\%) are in agreement with the statement. Taking into account that $82 \%$ of the respondents regard the tax function as their responsibility, it is a significant positive response and it can be concluded that this principle of the cognitive evaluation theory holds true for tax compliance behaviour. Although most of the small businesses make use of a tax practitioner, a further statistical test (an independent-samples t-test) indicated that there was no significant difference between the opinion of those respondents making use of a tax practitioner and those not using a tax practitioner, in relation to this specific statement $(\mathrm{t}=0.281 ; p=.779)$. In other words, most respondents interpret the reward as confirming their own competence, even if a tax practitioner has completed the tax return.

Using an independent-samples t-test, a significant difference in scores was found between male and female respondents in relation to this statement $(\mathrm{t}(170)=-2.223$ and $p=.028$ (2-tailed)). Possible reasons are a matter of speculation, which may include the level of education and the level of self-confidence. Research by Business Environment Specialists (2013) on women entrepreneurs found that women entrepreneurs in South Africa have, on average, a lower level of 
education and lower levels of self-confidence than their male counterparts. Therefore, being recognised for performing well in the business environment may be more important to women than men.

Statement 4 elicited opinions on whether a reward scheme will make the respondent feel appreciated by government for being tax compliant.

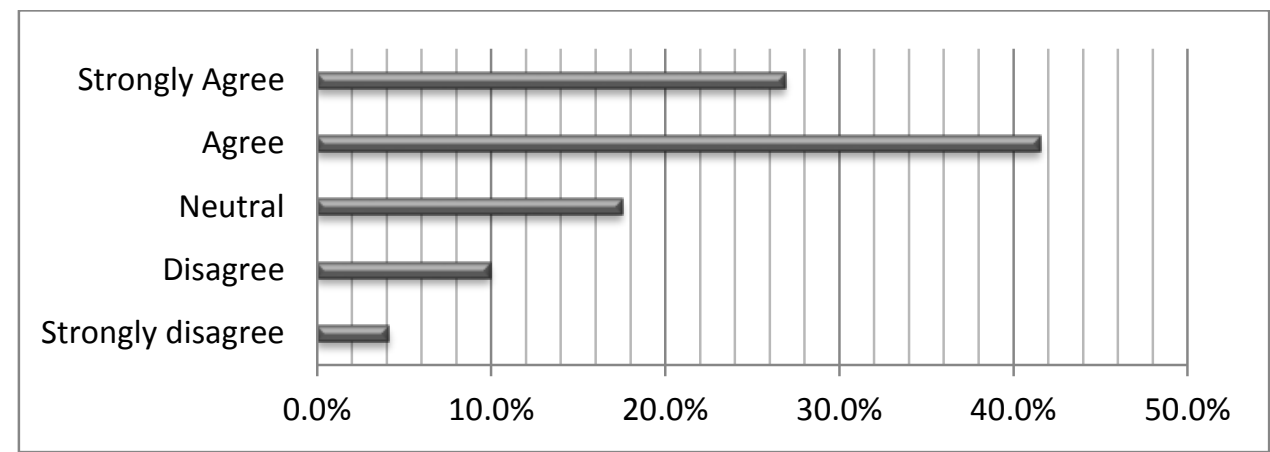

\section{FIGURE 5: Responses to statement $4(n=171)$}

Source: Authors' results

More than $68 \%$ of the respondents were in agreement that a reward will make them feel appreciated by government. A study by Kunz and Linder (2012) illustrated that affiliative rewards (signals of appreciation and recognition by peers or superiors linked to a strengthening of social ties) interact positively with enjoyment-based motivation. This confirms that when rewards convey a message of appreciation, it will enhance a sense of autonomy. This principle of the cognitive evaluation theory is therefore also confirmed for tax compliance behaviour, with respect to the current sample.

Statement 5 relates to the belief that a reward for tax compliance will signify that government is serious about acknowledging citizens as important role players in the economic wellbeing of the country.

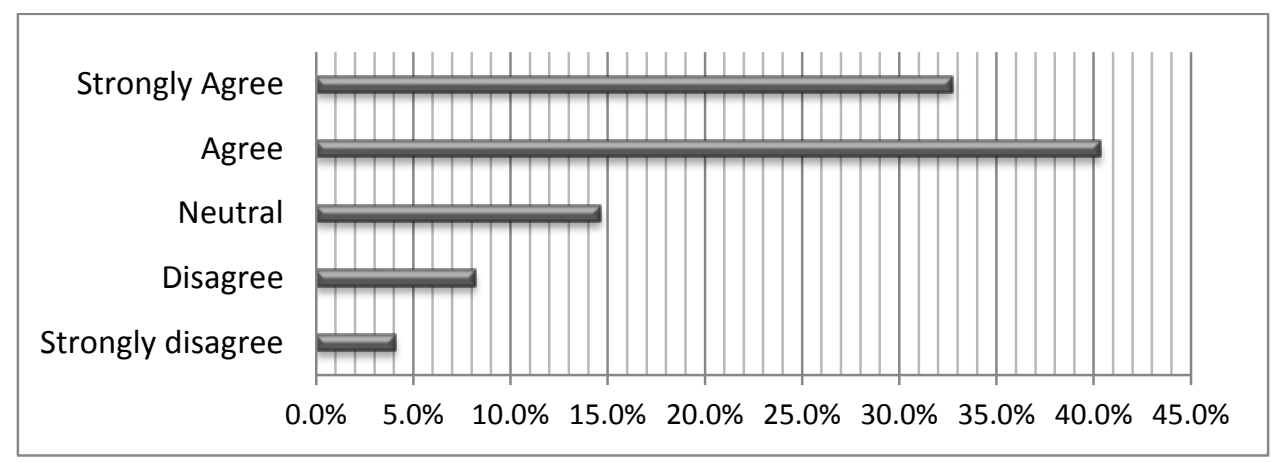

FIGURE 6: Responses to statement $5(n=171)$

Source: Authors' results 
More than $73 \%$ of respondents are in agreement that a reward for tax compliance will be a token of recognition, in this case recognising the taxpayer's contribution to the economy. One of the principles of the cognitive evaluation theory is that rewards should give recognition, and this recognition should be in acknowledgement of the behaviour that drives the action. Frey and Jegen (2001) suggested that when outside intervention carries the notion that the individual's motivation is not acknowledged, the intrinsic motivation of the individual is effectively rejected. When this happens, individuals may feel that their involvement is not appreciated and this may lead to a reduced effort by some individuals. It is evident from the present survey that the majority of respondents in this sample will perceive a reward as recognition of their motivation for paying taxes.

For this statement, women also scored relatively higher than men, although the effect was not statistically significant $(\mathrm{t}(171)=-1.807$ and $p=.073$ (2-tailed)). This difference, it is submitted, may be due to the fact that women entrepreneurs place a high value on making a social contribution. Research by Business Environment Specialists (2013) found that many women in developed economies are attracted to entrepreneurship by the desire to make a social contribution, while male owners were more likely to start a business to make money.

\subsubsection{Other comparisons between groups}

Additional tests using the independent-samples t-test and one way analysis of variance test, where appropriate, indicated no statistically significant difference in scores between groups with regard to the following variables: types of industry; size of business; level of education; race; and age of respondents.

\subsubsection{Internal consistency}

The most popular method for estimating internal consistency is the Cronbach's alpha $(\alpha)$ (Carmines \& Zeller, 1979), and was used in the present study as a reliability indicator. After statement 2 was reverse coded, the scale showed good internal consistency $(\alpha=0.825)$ in the responses to the statements.

\section{CONCLUSION}

Previous experimental research on the use of rewards to encourage tax compliance behaviour found that, in general, rewards had a positive effect on tax compliance behaviour and it was suggested by most researchers that governments should look beyond strategies of greater enforcement and should pursue a range of approaches to promote tax compliance. The results of the present survey, relating to the opinions expressed by the respondents included in the sample, indicate that attitudes towards the rewarding of tax compliance are mostly positive.

The results show that rewards are more strongly favoured as a strategy to encourage tax compliance than penalties (statement 1 ) and that the majority of respondents are not averse to being rewarded for performing an action required by law (statement 2). The results of statements 3 to 5 indicated that the principles of the cognitive evaluation theory with regard to the rewarding of intrinsically motivated behaviour hold true for tax compliance behaviour for the sample used in the survey. 
It is suggested that further research could be conducted to include the opinions of policymakers and other stakeholders, such as tax practitioners and SARS officials, on the application of a reward strategies to encourage tax compliance. In addition, reward strategies already applied in other countries could be reviewed to assess their usefulness in the South African tax arena and to identify possible opportunities or pitfalls.

\section{LIST OF REFERENCES}

Alm, J., Jackson, B.R. \& McKee, M. (1992). Estimating the determinants of taxpayer compliance with experimental data. National Tax Journal, 45(1), pp.107-14.

Alm, J., Kirchler, E. \& Muehlbacher, S. (2012). Combining Psychology and Economics in the Analysis of Compliance: From Enforcement to Cooperation. Economic Analysis \& Policy, 42(2), pp.133-51.

Ariely, D., Bracha, A. \& Meier, S. (2009). Doing Good or Doing Well? Image Motivation and Monetary Incentives in Behaving Prosocially. American Economic Review, 99 (1), pp.544-55.

Bazart, C. \& Pickhardt, M. (2009). Fighting Income Tax Evasion with Positive Rewards; Experimental Evidence. Research Document no 2009-01. Montpellier: LAMETA.

Bornman, M. (2014). Principles for understanding, encouraging and rewarding voluntary tax compliance. Unpublished Doctoral Thesis. Johannesburg: University of Johannesburg.

Braithwaite, V. (2002). A New Approach to Tax Compliance. In Braithwaite, V. Taxing Democracy. Hants: Ashgate Publishing Ltd. pp.1-11.

Business Environment Specialists. (2013). Understanding Women Entrepreneurs in South Africa. Available at: www.sbp.org.za. (Accessed 10 June 2014).

Callihan, D.S. \& Spindle, R.M. (1997). An Examination of Contingent and Non-contingent rewards in a Tax Compliance Experiment. Advances in Taxation, 9, pp.1-23.

Carmines, E.G. \& Zeller, R.A. (1979). Reliability and Validity Assessment, SAGE Publications, Inc., Thousand Oaks, CA. http://0-dx.doi.org.ujlink.uj.ac.za/10.4135/9781412985642. (Accessed 2 September 2014).

Cash Economy Task Force. (1998). Improving Tax Compliance in the Cash Economy, April 1998. Canberra: Australian Taxation Office. http://www.ato.gov.au/General/How-we-checkcompliance/Previous-years/Cash-economy/Task-force-reports/Improving-Tax-Compliance-in-theCash-Economy,-April-1998/. (Accessed 12 January 2014).

Cash Economy Task Force. (2003). The Cash Economy under the New Tax System. Commonwealth of Australia. https://www.ato.gov.au/Media-centre/Media-releases/Cash-economy-taskforcereport./ (Accessed 14 August 2013).

Deci, E.L., Koestner, R. \& Ryan, R.M. (1999). A Meta-Analytic Review of Experiments Examining the Effects of Extrinsic Rewards on Intrinsic Motivation. Psychological Bulletin, 125(6), pp.627-68.

EMM. (2013). Draft Annual Report. Boksburg: Ekurhuleni Metropolitan Municipality.

Fehr, E. \& Falk, A. (2002). Psychological Foundations of Incentives. Working Paper no. 507. Zurich: Center for Economic Studies \& IFO Institute for Economic Research Institute for the Study of Labor. http://ssrn.com/abstract_id=294287. 
Feld, L.P. \& Frey, B.S. (2003). The Tax Authority and the Taxpayer: An Exploratory Analysis. CiteSeer Available at:

http://citeseerx.ist.psu.edu/viewdoc/download?doi=10.1.1.200.8641\&rep=rep1\&type=pdf (Accessed 18 February 2014).

Feld, L.P. \& Frey, B.S. (2007). Tax Compliance as the Result of a Psychological Tax Contract: The Role of Incentives and Responsive Regulation. Law \& Policy, January, pp. 102-20.

Feld, L.P., Frey, S. \& Torgler, B. (2006). Rewarding Honest Taxpayers? Evidence on the impact of rewards from field experiments. Working Paper No 2006-16. Basel: Centre for Research in Economica, Management and the Arts.

Frey, B. \& Holler, M. (1998). Tax Compliance Policy Reconsidered. Homo Oeconomicus, xv(1), pp.2744.

Frey, B.S. \& Jegen, R. (2001). Motivation Crowding Theory. Journal of Economic Surveys, 15(5), pp.589611.

Grasmick, H.G. \& Scott, W.J. (1982). Tax Evasion and Mechanisms of Social Control: a Comparison with Grand and Petty Theft. Journal of Economic Psychology, 2, pp.213-30.

Kastlunger, B., Lozza, E., Kirchler, દ. \& Schabmann, A. (2013). Powerful authorities and trusting citizens: The Slippery Slope Framework and tax compliance in Italy. Journal of Economic Psychology, 34, pp.36-45.

Kastlunger, B., Muehlbacher, S., Kirchler, \&. \& Mittone, L. (2011). What Goes Around Comes Around? Experimental Evidence of the Effect of Rewards on Tax Compliance. Public Finance Review, 39(1), pp.150-67.

Kirchler, E., Hoelzl, E. \& Wahl, I. (2007). Enforced versus Voluntary Tax Compliance: The Slippery Slope Framework. Journal of Economic Psychology, pp.210-25.

Kirchler, E., Muehlbacher, S., Kastlunger, B. \& Wahl, I. (2007). Why Pay Taxes? A Review of Tax Compliance Decisions. Working Paper 07-30. Atlanta: Georgia State University Andrew Young School of Policy Studies.

Kunz, J. \& Linder, S. (2012). Organizational Control and Work Effort - Another Look at the Interplay of Rewards and Motivation. European Accounting Review, 21(3), pp.591-621.

Lacetera, N. \& Macis, M. (2010). Do all material incentives for pro-social activities backfire? The response to cash and non-cash incentives for blood donations. Journal of Economic Psychology, 31, pp.738-48.

Langham, J., Paulsen, N. \& Hartel, C.E. (2012). Improving tax compliance strategies: can the theory of planned behavior predict business compliance. eJournal of Tax Research, 10(2), pp.364-402.

Leedy, P. D., \& Ormrod, J. E. (2010). Practical Research: Planning and Design, $9^{\text {th }}$ edition. Boston: Pearson Education, Inc.

Martin, S. \& Dolan, P. (2010). Dear Taxpayer, Congratulations! You've Won Your Money Back. Available at: http://blogs.hbr.org/2010/12/dear-mr-taxpayer-congratulatio/ (Accessed 11 May 2014).

Murphy, K. (2005). Regulating More Effectively: The Relationship between Procedural Justice, Legitimacy, and Tax Non-compliance. Journal of Law and Society, 32(4), pp.562-89.

National Taxpayer Advocate. (2010). Annual Report to Congress. Annual report. Washington D.C.: IRS. 
0દCD. (2009). Managing and Improving Compliance: Recent Developments in Compliance Risk Treatments. Information Note. Centre for Tax Policy and Administration.

Pickhardt, M. \& Prinz, A. (2014). Behavioral dynamics of tax evasion - A survey. Journal of Economic Psychology, 40, pp.1-19.

Ryan, R.M. \& Deci, E.L. (2000). Intrinsic and Extrinsic Motivations: Classic Definitions and New Directions. Contemporary Educational Psychology, 25, pp.54-67.

SARS. (2012). Compliance Program 2012-2016. South African Revenue Service. Available at: http://www.sars.gov.za/AlIDocs/SARSEntDoclib/Ent/SARS-Strat-07-G02+-

+Compliance+Programme+2012+2013+to+2016+2017+\% \%2\%80\%93+External+Guide.pdf. (Accessed 11 March 2014).

Smulders, S. \& Naidoo, G. (2013). Addressing the Small Business Tax Compliance Burden - Evidence from South Africa. Journal of Economic and Financial Sciences, 6(1), pp.33-53.

The Commonwealth Association of Tax Administrators. (2006). Tax Evasion and Avoidance: Strategies and Initiatives used by CATA Member Countries. Hampshire: Commonwealth Secretariate.

Torgler, B. (2003). Beyond Punishment: A Tax Compliance Experiment with taxpayers in Costa Rica. Revista de Analisis Economico, 18(1), pp.27-56.

Turner, J. (2005). Explaining the nature of power: A three-process theory. European Journal of Social Psychology, 35, pp.1-22.

Tyler, T.R. (2006). Why People Obey the Law. Princeton, New Jersey: Princeton University Press. 